Антонюк 0. Р., д.е.н., доцент

(Національний університет водного господарства та природокористування, м. Рівне)

\title{
РИЗИКИ ВЗАЕМОДІї АУДИТОРА ТА ЗАМОВНИКА В КОНТЕКСТІ НЕЗАЛЕЖНОСТІ: ТЕНДЕНЦІї ЗАКОРДОННИХ ДОСЛІДЖЕНЬ
}

У статті розглянуто ризики, що виникають в процесі формування договірних відносин та безпосередньо у ході надання неаудиторських послуг. Основна увага приділена дотриманню незалежності в ході одночасного надання послуг 3 аудиту та інших послуг. Питання розглядається 3 акцентом на закордонний досвід теорії та практики ризиків професійної діяльності аудиторів в історичному контексті. Вказані напрями забезпечення професійної незалежності в частині неаудиторських послуг.

Ключові слова: ризик; незалежність; професійна діяльність; взаємодія; аудиторські послуги; неаудиторські послуги.

Постановка проблеми. Існуючі економічні процеси, що пов'язані зі зміною технологічних, організаційних та методичних підходів забезпечення підприємницької діяльності та нові умови національної економіки впливають на аудиторську діяльність. Вони ставлять нові завдання, вимагають комплексного, виваженого підходу до розв'язання існуючих проблем. У зв'язку 3 цим Бондар М.І. зазначає, що першочергового значення набуває проблема подальшого підвищення якості проведення аудиторської діяльності на основі розширення незалежності аудитора, підвищення професійних кваліфікаційних характеристик та впровадження в практику ефективних методично-розроблених аудиторських процедур [1, С. 145].

Аналіз досліджень та публікацій. Питання ефективності роботи зовнішнього аудитора багатогранне та включає багато аспектів. Однак, основним у справі забезпечення довіри до фінансової звітності з боку громадськості $€$ створення для аудитора таких умов і робочого оточення, в якому він міг об'єктивно працювати над матеріалами для забезпечення надійної інформації, яка є важливою для прийняття користувачами управлінських рішень. У розрізі різних аспектів незалежності необхідно визначити та проаналізувати чинники впливу на незалежність та застережні заходи, які необхідно при цьому вжити.

Невирішені раніше частини загальної проблеми. Розглядаючи 
дане питання в контексті Закону України «Про аудит фінансової звітності та аудиторську діяльність», слід зазначити, що на рівні законодавчого документу було акцентовано увагу на дотриманні незалежності при виконанні аудиту фінансової звітності суб'єктів суспільного інтересу в контексті виконання неаудиторських послуг. Проте, на даний час питання практичної реалізації вказаних положень, а також роботи аудитора при наданні неаудиторських послуг іншим категоріям замовників достатньо не розглянуто.

Постановка завдання. Завданням статті $\epsilon$ аналіз сучасних тенденцій розвитку різних аспектів незалежності 3 урахуванням закордонного досвіду, оцінка можливості застосування в Україні.

Основні результати дослідження. Важливість питань етики підкреслюють Замула І. В., Левківська О.Я. [2], також це питання $є$ одним з головних у розкритті у професійній літератур, має відображення на рівні документів професійної організації. Принцип незалежності та умови його забезпечення змінюються на вимогу умов та факторів провадження аудиторської діяльності, що відкликаються у зміні нормативної бази з цього питання як на рівні міжнародної стандартизації, так і в Україні.

У вивченні питання дотримання незалежності аудиторів в процесі надання аудиторських послуг простежуються наступні напрями досліджень у працях закордонних вчених (табл. 1).

Таблиця 1

Напрями наукових пошуків закордонних науковців в питанні дотримання принципу незалежності

\begin{tabular}{|c|c|c|}
\hline Автор & Рік & Напрямок наукових досліджень \\
\hline Antle R. [3] & 1984 & $\begin{array}{l}\text { Принцип незалежності в процесі надання } \\
\text { аудиторських послуг. }\end{array}$ \\
\hline Asbaugh H. та ін. [4] & 2003 & $\begin{array}{l}\text { Порушення принципу незалежності } \\
\text { процесі надання аудиторських послуг. }\end{array}$ \\
\hline $\begin{array}{l}\text { Beattie V., Fearnley S. } \\
\text { [5], Craswell A.T., } \\
\text { Stokes D., Laughton J. } \\
\text { [6] }\end{array}$ & 2002 & $\begin{array}{l}\text { Дотримання принципу незалежності в } \\
\text { процесі надання неаудиторських послуг. }\end{array}$ \\
\hline $\begin{array}{l}\text { Canning M., } \\
\text { Gwilliam D. [7] }\end{array}$ & 1999 & \\
\hline Creswell A. та ін. [8] & 2000 & Взаємозалежність між винагородою за \\
\hline Vaicekauskas D. [9] & 2012 & $\begin{array}{l}\text { аудиторські послуги та незалежністю } \\
\text { аудиторів. }\end{array}$ \\
\hline Brandon D.M. [10] & 2004 & Взаємозв'язок між незалежністю \\
\hline $\begin{array}{l}\text { Gul F.A.,Jaggi B.L., } \\
\text { Krishnan G.V. [11] }\end{array}$ & 2007 & $\begin{array}{l}\text { аудиторів та вартістю неаудиторських } \\
\text { послуг. }\end{array}$ \\
\hline
\end{tabular}


продовження табл. 1

\begin{tabular}{|l|l|l|}
\hline $\begin{array}{l}\text { Zhang B., Emanuel D. } \\
\text { [12] }\end{array}$ & 2008 & $\begin{array}{l}\text { Дотримання незалежності аудитора в } \\
\text { процесі надання послуг оподаткування. }\end{array}$ \\
\hline Schmidt J.J. [13] & 2008 & $\begin{array}{l}\text { Консервативний підхід у формуванні } \\
\text { вартості неаудиторських послуг. }\end{array}$ \\
\hline $\begin{array}{l}\text { Callaghan J., Parkash } \\
\text { M., Singhal R. [14] }\end{array}$ & $\begin{array}{l}\text { Особливості реалізації дотримання } \\
\text { принципу незалежності в процесі } \\
\text { надання неаудиторських послуг 3 } \\
\text { формування висновків аудитора в оцінці } \\
\text { безперервності діяльності підприємства. }\end{array}$ \\
\hline
\end{tabular}

Джерело: складено автором

Усе більше зростає одностайне відношення до проблеми незалежності в роботі аудитора, продовжують відбуватись випадки загроз незалежності аудитора на практиці, що пов'язане з різними чинниками, серед яких основну причину закордонні вчені вбачають у питанні оплати за аудиторські послуги. Ця ситуація вимагає застосування застережних засобів для захисту ідеї незалежності. На думку Nouri Hossein, Lombardi Danielle важливо переглянути питання незалежності аудитора та базових постулатів аудиту 3 врахуванням зміни економічних умов діяльності, адже науковці досліджували питання незалежності аудиторів, починаючи з праці класика аудиту Монтгомері та його постулатів до наукових надбань у 20 столітті [15].

Підтримуємо думку Манько А. Ф., що характер угод і завдань може різнитися, і, відповідно, можуть існувати різні загрози незалежності, що вимагають застосування і різних запобіжних заходів [16, С. 40]. Суттєвий вплив на незалежність аудитора також чинять гонорари та ціни, особливо в тому випадку, коли гонорар, визначений клієнтом, являє собою значну частину загальної суми гонорарів аудиторської фірми, оскільки виникає залежність від такого клієнта та занепокоєність щодо можливості його втрати. Значущість такої загрози залежатиме від структури та авторитету фірми.

Науковці зосередились на питанні дотримання незалежності під час надання послуг аудиту фінансової звітності та аудиторських послуг. Багато років дослідники з питань бухгалтерського обліку та аудиторської діяльності вивчають питання надання послуг клієнту 3 обліку, оцінки, актуарних послуг, послуг з оподаткування та інших. Дослідження вивчають сприйняття аудиторської незалежності, поведінки інвесторів та реакції на ринку, а також ролі корпоративного управління у сприйнятті неаудиторських послуг. 
Дослідження науковців свідчать, що винагорода, отримана від аудиторських послуг не впливає на думку інвесторів про незалежність аудитора. Рішення керівництва запросити цього ж аудитора для надання послуг аудитора можуть поставити під загрозу незалежність аудитора, проте фактично на практиці не погіршує незалежність.

Такі дослідження проводять науковці різних країн, оскільки законодавство окремих країн має певні особливості в питаннях регулювання незалежності. Так, у 2014 метою дослідження нігерійських вчених Okaro S. C., Okafor G. O. було питання про те, чи спільне надання аудиту та аудиторських послуг погіршує незалежність аудитора, та якщо так, то які $€$ регуляторні важелі у регулюванні даного питання. В результаті вчені дійшли висновку, ґрунтуючись на результатах опитування професійних бухгалтерів, що надання аудиторських послуг клієнтам 3 аудиту погіршує незалежність аудиторів, як наслідок було запропоновано внести законодавчі документи з обмеження у надання певних аудиторських послуг та аудиту в межах одного клієнта [17].

Одним 3 напрямків дослідження зв'язку між аудитом та аудиторськими послугами є вивчення впливу наданих аудиторських послуг на майбутні замовлення аудиту та з'ясування питання дотримання незалежності аудиторів при цьому. Дослідження показали, що має місце зв'язок між наданням аудиторських послуг та замовлень аудиту фінансової звітності зі сторони цього ж клієнта у наступному періоді, проте це замовлення виникає 3 причини поширення знань клієнта в результаті виконання аудиторської послуги, що і стимулює в подальшому клієнта робити замовлення 3 аудиту фінансової звітності. Результати досліджень цих авторів вказують на те, що аудиторські послуги $є$ надзвичайно корисними для клієнтів з аудиту [18].

Ohman Peter розглядалось вплив етичної культури аудитора на якість аудиту в умовах обмежень вартості та часу на його виконання на прикладі діяльності суб'єктів аудиторської діяльності в Швеції. Це дозволило на підставі розрахунків встановити, що недостатня кількість часу на проведення аудиту не впливає на етичну культуру, але тісно пов'язана з обмеженням винагороди, у свою чергу, таке обмеження зазвичай не впливає на якість аудиту. Водночас науковці довели на прикладі Швеції, що застосування важелів впливу на аудиторів за порушення принципів етики не пов'язані зі зменшення кількості аудитів фінансової звітності [19]. 
Проблема впливу аудиторських послуг на рівень незалежності аудитора $є$ за твердженням науковців, зокрема Шалімової Н.С., більш складною. «3 одного боку, їх надання дозволяє аудитору отримати інформацію щодо діяльності та операцій клієнта, яка є надзвичайно корисною, оскільки дозволяє краще зрозуміти процедури клієнта, заходи контролю, а також ділові та фінансові ризики, з якими він стикається» [20, С. 28]. «Крім того, в цьому випадку аудитор має більше контактів з керівництвом компанії клієнта, що дозволяє йому надійніше оцінити його чесність та фактори, які впливають на його поведінку. 3 іншого боку, вважається, що аудитор не може залишатися повністю об'єктивним при перевірці фінансових даних компанії, якій його фірма надає консультаційні послуги» [20, С. 28]. Отже, більшість фахівців визнають, що надання інших послуг клієнтам 3 надання впевненості, особливо клієнтам 3 аудиту фінансових звітів, $є$ основною для виникнення конфлікту інтересів» [20, С. 28].

Аудитори пропонують своїм клієнтам широкий спектр послуг 3 фінансових питань і менеджменту, оскільки під час роботи він досить добре ознайомився з діяльністю клієнта. Здійснюючи професійні послуги, аудитори дають різного роду рекомендації, зокрема й такі, що стосуються податків. Більше того, аудит містить у собі перевірку системи внутрішнього контролю, що обов'язково викликає пропозиції з поліпшення іï роботи. Якщо аудитор, окрім виконання аудиторських функцій надає клієнту інші послуги, то при цьому слід контролювати, щоб він не виконував керівних функцій і не приймав керівні рішення, відповідальність за які залишається за керівництвом. Для усунення чи зменшення загрози, яка при цьому виникає, до прийнятного рівня необхідно укласти угоду про те, що персонал, який надає такі послуги, не братиме участі у проведенні аудиту, та залучити додаткового професіонала для консультацій щодо визначення потенційного впливу діяльності на незалежність фірми та аудиторської групи.

Відповідальність за дотримання принципу незалежності покладена на аудиторську фірму, вона перевіряє дотримання принципу незалежності своїх працівників від замовника, використовуючи рекомендації міжнародних стандартів аудиту. При цьому має бути використання різних керівників груп з завдання 3 розмежованим підпорядкуванням при наданні послуг, що не стосуються послуг з надання впевненості.

Проблема дотримання принципу незалежності під час виконання аудиторських послуг на даний час менше контролюється 
професійними організаціями, зокрема Аудиторською палатою України. Це пов'язано з наступними причинами:

- незначне коло зовнішніх користувачів аудиторських послуг;

- відсутність оприлюднення матеріалів виконання аудиторської послуги перед третіми сторонами;

- недостатнє нормативне регулювання принципів, змісту, порядку виконання, підсумкової документації аудиторської послуги, $\mathrm{i}$, як наслідок, чітко ідентифікованих об'єктів контролю якості, i дотримання принципів етики.

Отже, дотримання принципів етики під час виконання аудиторських послуг на практиці пов'язане 3 професійною порядністю та чесністю конкретного аудитора. Напрямком зміни ситуації $\epsilon$ запровадження зовнішнього та внутрішнього контролю якості роботи аудитора при виконанні аудиторських послуг. Крім цього, в процесі виконання аудиту та наданні аудиторських послуг закордонні науковці особливий акцент ставлять на ролі аудиторських послуг в процесі взаємодії зовнішніх та внутрішніх аудиторів, що зокрема простежується у роботі Bame-Aldred C.W. та iн. [21].

На нашу думку, саме наявні документи зі зовнішнього контролю якості аудиторських послуг і визначатимуть орієнтири аудитору в організації власної внутрішньої системи контролю якості виконання аудиторських послуг з дотриманням принципів етики при їх виконанні. Зовнішній контроль з боку професійних організацій за умови його незалежного, неупередженого та якісного виконання $\epsilon$ додатковим стимулом для якісної роботи. На думку окремих вчених та практиків аудиту, такий контроль може здійснюватись як з боку професійної організації шляхом обов'язкових періодичних перевірок, так і з боку іншого аудитора (аудиторської фірми) на договірній основі. В першу чергу, аудиторська фірма повинна встановити політику та процедури, що забезпечать впевненість у тому, що персонал фірми та залучені фахівці до виконання договору аудиторських послуг, на яких поширюються вимоги незалежності та інші принципи професійної поведінки дотримуються них.

Сьогодні потрібно більш чітко розробити положення і роз'яснення стосовно виконання умов етичної поведінки аудиторів України.

У своїй практичній діяльності аудитор стикається практично 3 усіма загрозами, які сформульовані у МСА, як такі, що можуть призвести до порушення фундаментальних принципів професійної діяльності (чесності, об'єктивності, компетентності, конфіденційності, 
професійної поведінки). Одне з питань, яке впродовж більш ніж 30 років обговорюється в США - це дотримання принципу незалежності у разі надання аудиторських послуг (для своїх клієнтів 3 аудиту). Не дивлячись на зрозумілість принципу незалежності питання про аудиторські послуги в США (щодо яких застосовують категорію не аудиторські послуги) $є$ досить важливою темою для обговорення. Фахівцями США на підставі досліджень було наведено досить вагомі аргументи на користь наявності економічного взаємозв'язку між аудиторами та клієнтами у разі надання не аудиторських послуг. Водночас інші закордонні вчені вважають, що виконання аудиторських послуг збільшує знання аудитора про бізнес клієнта, що є сприятливим для ефективного проведення аудиторської перевірки.

Історія розгляду цієї теми була започаткована у 1980 році у працях Cowen, надалі у 1988 році Hall розглядає питання втрати незалежності у зв'язку з розширенням сфери аудиторських послуг. На рівні нормативного регулювання перші спроби Комісії з цінних паперів і бірж США з врегулювання принципу незалежності у разі надання аудиторських послуг були сприйняті аудиторською спільнотою зі скептицизмом. Мали місце сумніви щодо можливості втрати незалежності у зв'язку з продажем аудиторських послуг, а також побоювання, що нормативні документи завдадуть шкоди економічній життєздатності аудиторських фірм. Частина науковців стверджували, що значні суми, які сплачуються клієнтами як плата за аудиторські послуги може створювати економічний зв'язок, який неминуче послаблює умови незалежності аудиторів.

у 2000-х роках скандали у сфері аудиторської діяльності, пов'язані $з$ відомими компаніями переорієнтували наведену вище дискусію та призвели до регулятивних рішень, які змінили становище аудиторських фірм, які заборонили надавати більшу частину видів аудиторських послуг для клієнтів 3 аудиту. У наступному десятилітті був вибух наукових досліджень з приводу незалежності аудиторів та надання аудиторських послуг. Незважаючи на консенсус досліджень і часто висловлюваний скептицизм з боку аудиторів на обмеження аудиторських послуг, багато науковців продовжували висловлювати переконання, що надання послуг клієнтам аудиту знижують якість аудиту фінансової звітності.

Науковець Monika Causholli у 2014 році поставила за мету вивчити питання незалежності з нової точки зору. Усі попередні дослідники вивчали зв'язок між аудиторськими послугами та 
аудитом у ретроспективі як дозволене одночасне надання окремих аудиторських послуг в межах одного клієнта, a Monika Causholli вважає, що слід розглядати з точки зору майбутніх аудиторських послуг з боку клієнта з аудиту. Аналіз науковцем фінансових звітів аудиторських фірм на предмет надання аудиторських послуг, який забезпечив репрезентативну вибірку показав, що мали місце незвичні збільшення кількості аудиторських послуг у наступних роках, які мали раніше незначні обсяги аудиторських послуг. Таким чином, M. Causholli було висунуто гіпотезу, що незалежність аудитора, швидше за все буде порушена, якщо аудитори будуть активно пропонувати нові аудиторські послуги своїм клієнтам 3 аудиту. Слід зазначити, що дискусії 3 приводу принципу незалежності залишаються в активній фазі, про що вказують публікації у спеціалізованих виданнях останніх років у тому числі автора Антонюк O.P. [21; 22], що для українських практиків та науковців має становити предмет зацікавлення для врахування світових тенденцій аудиторської діяльності та специфіки їх впровадження в Україні.

Висновки та пропозиції. Проблема дотримання незалежності під час виконання аудиторських та неаудиторських послуг та ризику, що виникає при цьому в процесі взаємодії аудитора та замовника послуг на даний час не достатньо контролюється професійними організаціями в Україні. Це пов'язано з наступними причинами: незначне коло зовнішніх користувачів результату аудиторської послуги; відсутність оприлюднення матеріалів виконання послуги перед третіми сторонами; недостатнє нормативне регулювання принципів, змісту, порядку виконання, підсумкової документації, i, як наслідок, чітко ідентифікованих об'єктів контролю якості, i дотримання принципів етики. Отже, дотримання принципів етики під час виконання аудиторських послуг на практиці пов'язане 3 професійною порядністю та чесністю конкретного аудитора. Напрямком зміни ситуації $€$ посилення внутрішнього контролю якості роботи аудитора при виконанні аудиторських послуг. Водночас наявні документи зі зовнішнього контролю якості аудиторських послуг визначатимуть орієнтири аудитору в організації власної внутрішньої системи контролю якості виконання аудиторських послуг.

1. Бондар М. І. Розвиток аудиту в Україні. Ринок аудиторських послуг в Україні: стан $i$ перспективи розвитку : зб. матеріалів доповідей Міжнародної науково-практичної конференції (м. Івано-Франківськ, 15-16 квітня 2010 р.). Івано-Франківськ, 2010. С. 145-147. 2. Замула І. В., Левківська О. Я. Професійна етика бухгалтера і аудитора. 
Проблеми теорії та методології бухгалтерського обліку, контролю та аналізу. 2015. № 1(31). C. 156-164. 3. Antle R. Auditor independence. Journal of Accounting Research. 1984. Vol. 22. No. 1. Pp.1-20. 4. Asbaugh H., LaFond R., Mayhew B. Do non-audit services compromise auditor independence? Further evidence. The Accounting Review. 2003. Vol. 78. Issue 3. Pp. 611-639. 5. Beattie V., Feamley S. Auditor independence and non-audit services: a literature review (working paper). Institute of Chartered Accountants in England and Wales (ICAEW). 2004. URL: http://www.icaew.co.uk (дата звернення: 20.02.2020). 6. Craswell A.T., Stokes D., Laughton J. Auditor independence and fee dependence. Journal of Accounting and Economics. 2002. Vol. 33, Issue 2. Pp. 253-275. 7. Canning M., Gwilliam D. Non-audit services and auditor independence: Some evidence from Ireland. The European Accounting Review. 1999. N. 3(3). 1999. URL: 401-419. dx.doi.org/10.1080/096381899335853 (дата звернення: 20.02.2020). 8. Craswell A. T., Stokes D., Laughton J. Auditor independence and fee dependence. Journal of Accounting and Economics. 2002. Vol. 33, Issue 2. Pp. 253-275. 9. Vaicekauskas D. Differences between audit quality provided by international and local audit firms: the research on audit clients perceptions $i$ the audit market of Lithuania. Ekonomika, 2014. Pp.157-173. URL: http://search.proquest.com/docview/1644448235/fulltext/AF20F1E7C91E442APQ/41 ?accountid=17203

(дата звернення: 20.02.2020). 10. Brandon D. M., Crabtree A. D., Maher J. J. Nonaudit fees, auditor independence, and bond ratings. Auditing: A Journal of Practice \& Theory. 2004. Vol. 23. No. 2. Pp. 89-103. 11. Gul F. A., Jaggi B. L., Krishnan G. V. Auditor independence: evidence on the joint effects of auditor tenure and nonaudit fees. Auditing: A Journal of Practice \& Theory. 2007. Vol. 26, Issue 2. Pp. 117-142. 12. Zhang B., Emanuel D. The provision of non-audit services and earnings conservatism: Do New Zealand auditors compromise their independence? Accounting Research Journal. 2008. Pp. 195-221. URL: http://search.proquest.com/docview/214448303/fulltext/4FDA5C5E3FF34D0APQ/11?accountid=17203 (дата звернення: 20.02.2020). 13. Schmidt J. J. Perceived Auditor independence and audit litigation: the role of nonaudit services fees. The Accounting Review. 2012, May. URL: http://aaajournals.org/loi/ajpt. (дата звернення: 20.02.2020). 14. Callaghan J., Parkash M., Singhal R. Going concern audit opinions and the provision of nonaudit services: implications for auditor independence of Bankrupt firms. AUDITING: A Journal of Practice \& Theory. 2009, May. Vol. 28. No. 1. 15. Nouri H., Lombardi D. Auditors independence: an analysis of Montgomerys auditing textbooks in the $20^{\text {th }}$ century. The Accounting Historians Journal. 2009. Pp.81-112. URL: http://search.proquest.com/docview/523047361/fulltext/B411C273108D4269PQ/22? accountid=17203 (дата звернення: 20.02.2020). 16. Манько Н. Ф. Загрози незалежності аудиторського судження при виконанні завдань 3 надання впевненості. Стратегія розвитку аудиту в умовах глобалізації економічних відносин : тези доп. Міжнар. наук.-практ. конф. (Київ, 31 березня-1 квітня 2016 року) / відп. ред. А. А. Мазаракі. Київ : Київ. нац. торг.-економ. ун-т, 2016. С. 39-41. 17. Okaro S. С., Okafor G. O. Joint Provision of Audit and Non-Audit Services in Nigeria: An Empirical Study. IUP Journal of Accounting Research \& Audit Practices . 2014. Pp. 30-45. URL: http://search.proquest.com/docview/1511117268/fulltext/4FDA5C5E3FF34D0APQ/13 6? accountid=17203 (дата звернення: 20.02.2020). 18. Öhman P. and Eva Wallerstedt. Audit regulation and the development of the auditing profession: The case of Sweden. Accounting History. 2012. Рр. 241-257. 19. Шалімова Н. С. Аудит та інші послуги: проблеми забезпечення незалежності аудиторів. Економіка та держава. 2010. № 8. C. 25-28. URL: http://www. irbis-nbuv.gov.ua (дата звернення: 20.02.2020). 20. BameAldred C. W., Brandon D. M., Messier Jr. W. F., Rittenberg L. E., Stefaniak C. M. A summary of research on external auditor reliance on the internal audit function. Auditing: a Journal of Practice \& Theory. May 2013, Vol. 32. No. Supplement 1 (2013). 
Pp. 251-286. URL: http://aaajournals.org/loi/ajpt (дата звернення: 20.02.2020). 21. Antonyuk E. Diversification of audit services as a way to improve the effectiveness of auditing company. International Journal of New Economics and Social Sciences. Poland, $\quad$ Swinoujscie. $2016 . \quad$ № 1 (3). P. 55-63. URL: https://ijoness.com/resources/html/cms/MAINPAGE (дата звернення: 20.02.2020). 22. Antonyuk $E$. Issues and proposals for the improvement of standartization of audit services. International Journal of New Economics and Social Sciences. Poland, Swinoujscie. 2015. № 2 (2). P. 114-119. URL: https://ijoness.com/resources/html/cms/MAINPAGE (дата звернення: 20.02.2020).

\section{REFERENCES:}

1. Bondar M. I. Rozvytok audytu v Ukraini. Rynok audytorskykh posluh v Ukraini: stan $i$ perspektyvy rozvytku : zb. materialiv dopovidei Mizhnarodnoi naukovo-praktychnoi konferentsii (m. Ivano-Frankivsk, 15-16 kvitnia 2010 r.). Ivano-Frankivsk, 2010. S. 145147. 2. Zamula I. V., Levkivska O. Ya. Profesiina etyka bukhhaltera i audytora. Problemy teorii ta metodolohii bukhhalterskoho obliku, kontroliu ta analizu. 2015. № 1(31). S. 156164. 3. Antle R. Auditor independence. Journal of Accounting Research. 1984. Vol. 22. No. 1. Pp. 1-20. 4. Asbaugh H., LaFond R., Mayhew B. Do nonaudit services compromise auditor independence? Further evidence. The Accounting Review. 2003. Vol. 78. Issue 3. Pp. 611-639. 5. Beattie V., Feamley S. Auditor independence and nonaudit services: a literature review (working paper). Institute of Chartered Accountants in England and Wales (ICAEW). 2004. URL: http://www.icaew.co.uk (data zvernennia: 20.02.2020). 6. Craswell A.T., Stokes D., Laughton J. Auditor independence and fee dependence. Journal of Accounting and Economics. 2002. Vol. 33, Issue 2. Pp. 253-275. 7. Canning M., Gwilliam D. Non-audit services and auditor independence: Some evidence from Ireland. The European Accounting Review. 1999. N. 3(3). 1999. URL: 401419. dx.doi.org/10.1080/096381899335853 (data zvernennia: 20.02.2020). 8. Craswell A. T., Stokes D., Laughton J. Auditor independence and fee dependence. Journal of Accounting and Economics. 2002. Vol. 33, Issue 2. Pp. 253-275. 9. Vaicekauskas D. Differences between audit quality provided by international and local audit firms: the research on audit clients perceptions i the audit market of Lithuania. Ekonomika. 2014. Pp. 157-173.

URL: http://search.proquest.ᄀcom/docview/1644448235/fulltext/AF20F1E7C91E442APQ/4 1 ?accountid=17203 (data zvernennia: 20.02.2020). 10. Brandon D. M., Crabtree A. D., Maher J. J. Nonaudit fees, auditor independence, and bond ratings. Auditing: A Journal of Practice \& Theory. 2004. Vol. 23. No. 2. Pp. 89-103. 11. Gul F. A., Jaggi B. L., Krishnan G. V. Auditor independence: evidence on the joint effects of auditor tenure and nonaudit fees. Auditing: A Journal of Practice \& Theory. 2007. Vol. 26, Issue 2. Pp. 117-142. 12. Zhang B., Emanuel D. The provision of non-audit services and earnings conservatism: Do New Zealand auditors compromise their independence? Accounting Research Journal. $2008 . \quad$ Pp. 195-221. URL: http://search.proquest.ᄀcom/docview/214448303/fulltext/4FDA5C5E3FF34D0APQ/11 ?accountid=17203 (data zvernennia: 20.02.2020). 13. Schmidt J. J. Perceived Auditor independence and audit litigation: the role of nonaudit services fees. The Accounting Review. 2012, May. URL: http://aaajournals.org/loi/ajpt. (data zvernennia: 20.02.2020). 14. Callaghan J., Parkash M., Singhal R. Going concern audit opinions and the provision of nonaudit services: implications for auditor independence of Bankrupt firms. AUDITING: A Journal of Practice \& Theory. 2009, May. Vol. 28. No. 1. 15. Nouri H., Lombardi D. Auditors independence: an analysis of Montgomerys auditing textbooks in the 20th century. The Accounting Historians Journal. 2009. Pp. 81-112. URL: 
http://search.proquest.com/docview/523047361/fulltext/B411C273108D4269PQ/22? accountid=17203 (data zvernennia: 20.02.2020). 16. Manko N. F. Zahrozy nezalezhnosti audytorskoho sudzhennia pry vykonanni zavdan z nadannia vpevnenosti. Stratehiia rozvytku audytu $v$ umovakh hlobalizatsii ekonomichnykh vidnosyn : tezy dop. Mizhnar. nauk.-prakt. konf. (Kyiv, 31 bereznia-1 kvitnia 2016 roku) / vidp. red. A. A. Mazaraki. Kyiv : Kyiv. nats. torh.-ekonom. un-t, 2016. S. 39-41. 17. Okaro S. C., Okafor G. O. Joint Provision of Audit and Non-Audit Services in Nigeria: An Empirical Study. IUP Journal of Accounting Research \& Audit Practices. 2014. Pp. 30-45. URL: http://search.proquest.com/docview/1511117268/fulltext/4FDA5C5E3FF34D0APQ/13 6? accountid=17203 (data zvernennia: 20.02.2020). 18. Öhman P. and Eva Wallerstedt. Audit regulation and the development of the auditing profession: The case of Sweden. Accounting History. 2012. Rr. 241-257. 19. Shalimova N. S. Audyt ta inshi posluhy: problemy zabezpechennia nezalezhnosti audytoriv. Ekonomika ta derzhava. 2010. № 8. S. 25-28. URL: http://www. irbis-nbuv.gov.ua (data zvernennia: 20.02.2020). 20. BameAldred C. W., Brandon D. M., Messier Jr. W. F., Rittenberg L. E., Stefaniak C. M. A summary of research on external auditor reliance on the internal audit function. Auditing: a Journal of Practice \& Theory. May 2013, Vol. 32. No. Supplement 1 (2013). Pp. 251-286. URL: http://aaajournals.org/loi/ajpt (data zvernennia: 20.02.2020). 21. Antonyuk E. Diversification of audit services as a way to improve the effectiveness of auditing company. International Journal of New Economics and Social Sciences. Poland, Swinoujscie. 2016. № 1 (3). R. 55-63. URL: https://ijoness.com/resources/html/cms/MAINPAGE (data zvernennia: 20.02.2020). 22. Antonyuk E. Issues and proposals for the improvement of standartization of audit services. International Journal of New Economics and Social Sciences. Poland, Swinoujscie. 2015. № 2 (2). R. 114-119. URL: https://ijoness.com/resources/html/cms/MAINPAGE (data zvernennia: 20.02.2020).

Antoniuk 0. R., Doctor in Economics, Associate Professor (National University of Water and Environmental Engineering, Rivne)

\section{BUSINESS RELATION RISKS FOR AUDITOR AND CUSTOMER IN THE CONTEXT OF INDEPENDENCE: TRENDS IN FOREIGN RESEARCH}

The urgency of the issue in the context of the Law of Ukraine "On Audit of Financial Reporting and Auditing" is emphasized, since at the level of the legislative document the attention was paid to the observance of the independence of the financial statements of public interest entities in the context of performing non-audit services. However, at present, the practical implementation of these provisions, as well as the work of the auditor in providing non-audit services to other categories of customers is not sufficiently considered. The purpose of the study is to analyze current trends in the development of various aspects of independence in the light of foreign experience, assess the possibility of application in Ukraine.

The article deals with the risks that arise in the process of forming contractual relations and in the course of providing non-audit services. Emphasis is placed on maintaining independence in the simultaneous provision of audit and other services. The issue is addressed with a focus on the overseas experience of auditors' theory and practice of professional 
performance in a historical context. The development of non-audit services in Ukraine requires the research and practical implementation of aspects of auditors' professional behavior regarding their provision to audit clients. The foreign researches were analyzed: features of realization of independence observance in the process of rendering non-audit services for forming the auditor's conclusions in the assessment of continuity; the relationship between auditor independence and the price of non-audit services; the auditor's independence in the process of providing tax services. The article also raises the issue of quality control of the provision of non-audit services by professional organizations. Discussions about independence remain in the active phase, which should be of interest to Ukrainian auditors to take into account the global trends in audit activity and the specifics of their implementation in Ukraine. The directions of professional independence in the part of non-audit services are indicated.

Keywords: risk; independence, professional activity, interaction, audit services, non-audit services.

Антонюк Е. Р., д.э.н., доцент (Национальный университет водного хозяйства и природопользования,

г. Ровно)

\section{РИСКИ ВЗАИМОДЕЙСТВИЯ АУДИТОРА И ЗАКАЗЧИКА В КОНТЕКСТЕ НЕЗАВИСИМОСТИ: ТЕНДЕНЦИИ ЗАРУБЕЖНЫХ ИССЛЕДОВАНИЙ}

В статье рассмотрены риски, возникающие в процессе формирования договорных отношений, а также при предоставлении неаудиторских услуг. Основное внимание уделено соблюдению независимости в ходе одновременного предоставления услуг по аудиту и прочих услуг. Вопрос рассматривается с акцентом на зарубежный опыт теории и практики рисков профессиональной деятельности аудиторов с учетом исторического фактора. Определены направления обеспечения профессиональной независимости в части неаудиторских услуг.

Ключевые слова: риск; независимость; профессиональная деятельность; взаимодействие; аудиторские услуги; неаудиторские услуги. 